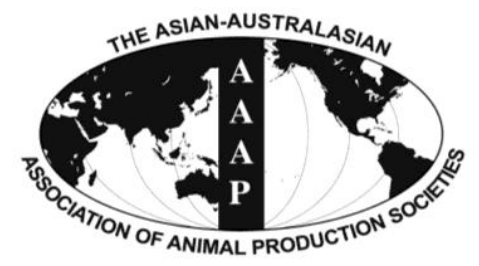

Asian-Aust. J. Anim. Sci.

Vol. 25, No. 3 : 428 - 434

March 2012

www.ajas.info

http://dx.doi.org/10.5713/ajas.2011.11296

\title{
The Quality of Modified Atmosphere Packaged Meat from Lambs Slaughtered at 50 and 100 Days of Age
}

\author{
Zenon Tański*, Milewski Stanisław and Zaleska Bożena \\ Department of Sheep and Goat Breeding, University of Warmia and Mazury in Olsztyn, \\ ul. Oczapowskiego 5, 10-719 Olsztyn, Poland
}

\begin{abstract}
The aim of this study was to determine the quality of modified atmosphere (MA) packaged meat from Pomeranian rams slaughtered at 50 and 100 days of age. Determined: chemical composition, physicochemical and sensory properties of meat, and the fatty acid profile of intramuscular fat. Meat from 100-d-old lambs was characterized by a significantly higher content of dry matter, total protein and crude fat, a darker color and higher physiological maturity ( $\mathrm{p} \leq 0.01)$. Meat from younger lambs was marked by a better water-holding capacity $(\mathrm{p} \leq 0.05)$, a lower energy value and higher concentrations of monounsaturated fatty acids (MUFA) and polyunsaturated fatty acids (PUFA). An increase in the content of dry matter, total protein and ash, and energy value was noted in MAstored meat. Meat $\mathrm{pH}$ decreased over MA storage and the sensory properties deteriorated. The studied meat remained safe from microbial contamination during storage. (Key Words : Meat Quality, Modified Atmosphere, Lamb Meat, Age)
\end{abstract}

\section{INTRODUCTION}

Recent years have witnessed lifestyle and nutrition changes, accompanied by increasing consumer demand for high-quality, preservative-free meat products with a long shelf-life. Current trends show that consumers prefer fresh, easy-to-prepare food products in smaller portions. Protective atmosphere gases can be used to preserve the freshness of foods, including meat. Fresh primal or retail cuts can be packaged under a modified atmosphere (MA). In this process, the internal atmosphere surrounding a product is modified with a selection of gases neutral to food. MA prevents surface drying and the loss of vitamins and aroma compounds during storage (Doherty et al., 1996; Krala, 1996; Sheridan et al., 1997; Pikul, 2000; Bąk et al., 2001). The use of oxygen-free MA, composed of 20 to $30 \%$ $\mathrm{CO}_{2}$ and 70 to $80 \% \mathrm{~N}_{2}$, maximizes the shelf-life extension effect (Christopher et al., 1980; Weber and Höpke, 1980; Krala et al., 1995; Krala, 1999). The shelf-life of fresh lamb meat stored in MA may vary widely depending on the composition of gas mixtures. According to Rokni et al. (2001), MA packaged lamb meat is fit for human consumption for 13 days, according to Vergara and Gallego

\footnotetext{
* Corresponding Author : Zenon Tański. Tel : +488952334-59, Fax : +48895233806, E-mail : tanzen@uwm.edu.pl Submitted Aug. 24, 2011; Accepted Oct. 28, 2011; Revised Nov. 3, 2011
}

(2001) up to 17 days, according to Christopher et al. (1980) and Doherty et al. (1996a) up to 28 days or 43 days (1996b), while according to Penny et al. (1995) and Sheridan et al. (1997) as long as 7 to 8 weeks. For best results, MA packaged meat should be stored at low, near cryoscopic temperatures $\left(0-4^{\circ} \mathrm{C}\right)$ causing the rate of chemical and microbial breakdown to slow (Krala, 1996; Kondratowicz and Bak, 2001; Barrera et al., 2007). The effect of MA packaging on the shelf-life extension of lamb meat remains poorly investigated, and the few studies conducted to date have focused mostly on microbiological safety issues.

In view of the above, the objective of this study was to determine changes in the physicochemical and sensory properties of lamb meat during MA storage.

\section{MATERIAL AND METHODS}

The experiment was conducted in a herd of Pomeranian sheep, one of the main meat-type breeds in Poland. The experimental material comprised 32 single-born suckling male lambs, the offspring of 4-year-old ewes, born at the same time. The animals were fed standard diets recommended by INRA (1988). Until 10 days of age, the lambs were fed exclusively on their mothers' milk. Starting from day 11, they received also meadow hay and $\mathbf{C J}$ concentrate, followed by maize silage offered from day 30 . 
The rams were slaughtered in accordance with the method recommended by the National Research Institute of Animal Production (Krupiński, 2009). 16 animals were slaughtered at 50 days of age and average body weight of $17.98 \mathrm{~kg}$, and the remaining 16 animals were slaughtered at 100 days of age and average body weight of $28.01 \mathrm{~kg}$. Samples for meat quality assessment were collected from $M$. quadriceps femoris of the right leg after 18 to $24 \mathrm{~h}$ of carcass chilling at $4^{\circ} \mathrm{C}$. The samples were divided into four equal groups. Those intended for MA storage were placed in trays and were packaged in polyamide/polyethylene (PA/PE) bags using the Tepro PP-5 vacuum packer. The PA/PE bags were characterized by the following gas permeability at a temperature of $23^{\circ} \mathrm{C}: 16-19 \mathrm{~cm}^{3} / \mathrm{cm}^{2} / 24 \mathrm{~h}$ for $\mathrm{O}_{2}, 100-130$ $\mathrm{cm} / \mathrm{cm}^{2} / 24 \mathrm{~h}$ for $\mathrm{CO}_{2}, 3-5 \mathrm{~g} / \mathrm{m}^{2} / 24 \mathrm{~h}$ for $\mathrm{N}_{2}$ and 2-3 g/m $/ 24 \mathrm{~h}$ for water vapor (Michniewicz, 1998). 99\% of atmospheric air was removed from the bags, and a gas mixture composed of $80 \% \mathrm{~N}_{2}$ and $20 \% \mathrm{CO}_{2}$ was injected. The samples were stored in a chilling room with forced ventilation, at $1 \pm 0.5^{\circ} \mathrm{C}$, for 10,20 and 30 days. The quality of fresh meat, stored for approximately $48 \mathrm{~h}$ at $4{ }^{\circ} \mathrm{C}$, and MA stored meat was compared. The following parameters were determined: dry matter - by drying at $105^{\circ} \mathrm{C}$, total protein - by the Kjeldahl method, crude fat - by the Soxhlet method, crude ash - by incineration at $550^{\circ} \mathrm{C}$, gross energy using a KL-10 adiabatic bomb calorimeter, water-holding capacity - by the filter paper press method of Grau and Hamm (1953), color brightness - using a Specol spectrometer and an $\mathrm{R} 45 / \mathrm{O}$ remission attachment, at a wavelength of $560 \mathrm{~nm}, \mathrm{pH}$ - using a Radiometer PHM 22 $\mathrm{pH}$-meter, fatty acid composition of intramuscular fat - by esterification (Peisker, 1964) followed by gas chromatography using a VARIAN CP-3800 chromatograph, at the following separation conditions: flame ionization detector FID, capillary column - length: $50 \mathrm{~m}$, internal diameter: $0.25 \mathrm{~mm}$, liquid phase - CP-Sil 88, film thickness $-0.25 \mu \mathrm{m}$, carrier gas - helium, flow rate $-1.2 \mathrm{ml} / \mathrm{min}$. The sensory properties of cooked meat (Baryłko-Pikielna, 1975), i.e. tenderness, juiciness, aroma (intensity and desirability) and taste (intensity and desirability), were assessed on a five-point scale. The microbial contamination of MA stored meat was also evaluated. For that purpose, sterile muscle samples were collected before MA packaging and immediately after opening the MA package, in accordance with PN-EN ISO 4833:2004.

The results were processed statistically by two-way analysis of variance, including age of lambs (50 and $100 \mathrm{~d}$ ) and MA storage period (10, 20 and $30 \mathrm{~d})$. The significance of differences between groups was verified with Duncan's test using Statistica 9.0 SoftCorp, Software.

\section{RESULTS AND DISCUSSION}

Both the age of lambs at slaughter (50 and $100 \mathrm{~d}$ ) and MA storage period (10, 20 and $30 \mathrm{~d}$ ) had a significant effect on the chemical composition and selected physicochemical properties of meat (Table 1). Meat from 100-d-old lambs was characterized by a higher content of dry matter, total

Table 1. Chemical composition and physicochemical properties of meat

\begin{tabular}{|c|c|c|c|c|c|c|c|}
\hline \multirow{2}{*}{ Specification } & & \multicolumn{2}{|c|}{ Age of lambs (d) } & \multicolumn{4}{|c|}{ Storage in a gas mixture (d) } \\
\hline & & 50 & 100 & 0 & 10 & 20 & 30 \\
\hline \multirow[t]{2}{*}{ Dry matter $(\%)$} & Mean & $22.30^{\mathrm{B}}$ & $23.87^{\mathrm{A}}$ & $22.05^{\mathrm{Bb}}$ & $22.57^{\mathrm{a}}$ & $22.92^{\mathrm{A}}$ & $23.01^{\mathrm{A}}$ \\
\hline & $\mathrm{SD}$ & 0.97 & 1.00 & 1.16 & 1.11 & 0.73 & 0.76 \\
\hline \multirow[t]{2}{*}{ Crude protein $(\%)$} & Mean & $18.59^{\mathrm{B}}$ & $19.86^{\mathrm{A}}$ & $18.34^{\mathrm{Bb}}$ & $18.93^{\mathrm{a}}$ & $19.11^{\mathrm{A}}$ & $19.25^{\mathrm{A}}$ \\
\hline & SD & 4.36 & 3.92 & 4.02 & 3.07 & 2.27 & 2.69 \\
\hline \multirow[t]{2}{*}{ Fat $(\%)$} & Mean & $1.43^{\mathrm{B}}$ & $1.84^{\mathrm{A}}$ & 1.66 & 1.65 & 1.70 & 1.75 \\
\hline & SD & 0.38 & 0.38 & 0.38 & 0.38 & 0.38 & 0.38 \\
\hline \multirow[t]{2}{*}{ Ash (\%) } & Mean & 1.13 & 1.14 & $1.12^{\mathrm{b}}$ & 1.13 & 1.13 & $1.14^{\mathrm{a}}$ \\
\hline & SD & 0.04 & 0.05 & 0.04 & 0.04 & 0.05 & 0.05 \\
\hline \multirow[t]{2}{*}{ Water-holding capacity $\left(\mathrm{cm}^{2}\right)$} & Mean & $8.34^{\mathrm{B}}$ & $8.90^{\mathrm{A}}$ & $7.61^{\mathrm{Bb}}$ & $8.79^{a}$ & $8.89^{\mathrm{A}}$ & $8.98^{\mathrm{A}}$ \\
\hline & SD & 0.10 & 0.11 & 0.11 & 0.08 & 0.09 & 0.10 \\
\hline \multirow[t]{2}{*}{ Color } & Mean & $20.74^{\mathrm{A}}$ & $18.63^{\mathrm{B}}$ & $17.96^{\mathrm{B}}$ & 18.51 & $19.31^{\mathrm{A}}$ & $19.41^{\mathrm{A}}$ \\
\hline & SD & 0.58 & 0.44 & 0.46 & 0.42 & 0.57 & 0.59 \\
\hline \multirow[t]{2}{*}{$\mathrm{pH}$} & Mean & 5.59 & 5.58 & $5.47^{\mathrm{A}}$ & $5.45^{\mathrm{A}}$ & $5.38^{\mathrm{Ba}}$ & $5.32^{\mathrm{Bb}}$ \\
\hline & SD & 0.06 & 0.05 & 0.02 & 0.03 & 0.05 & 0.06 \\
\hline \multirow[t]{2}{*}{ Water/protein ratio (W/P) } & Mean & $4.18^{\mathrm{A}}$ & $3.83^{\mathrm{B}}$ & $4.12^{\mathrm{A}}$ & $4.04^{\mathrm{a}}$ & $3.99^{\mathrm{B}}$ & $3.79^{\mathrm{Bb}}$ \\
\hline & SD & 0.18 & 0.20 & 0.17 & 0.22 & 0.20 & 0.18 \\
\hline \multirow[t]{2}{*}{$\mathrm{GE} / 100 \mathrm{~g}$} & Mean & $95.26^{\mathrm{B}}$ & $98.72^{\mathrm{A}}$ & $95.20^{\mathrm{Bb}}$ & $98.97^{\mathrm{a}}$ & $99.92^{\mathrm{A}}$ & $100.14^{\mathrm{Aa}}$ \\
\hline & $\mathrm{SD}$ & 5.80 & 6.54 & 4.82 & 5.05 & 5.22 & 5.35 \\
\hline
\end{tabular}

\footnotetext{
$\overline{a, b} \mathrm{p} \leq 0.05 .^{\mathrm{A}, \mathrm{B}} \mathrm{p} \leq 0.01$
} 
protein and crude fat $(\mathrm{p} \leq 0.01)$, compared with meat from lambs slaughtered at 50 days of age, which is consistent with the findings of Brzostowski et al. (1997) and Brzostowski and Tański (2008), who studied Kamieniec lambs and Pomeranian lambs, respectively. An increase in the concentrations of the above components in meat from older lambs contributed to a significantly higher energy value and physiological maturity of meat, estimated based on the water/protein $(\mathrm{W} / \mathrm{P})$ ratio $(\mathrm{p} \leq 0.01)$. Higher values of the W/P ratio (known as the Feder index) point to higher physiological maturity of meat from older lambs (3.83), compared with meat from younger lambs (4.18). Such a correlation has also been noted by Kaczor et al. (2000), Brzostowski and Tański (2008), and Tański et al. (2009). An increase in the protein and fat content of meat, accompanied by a decrease in water content, contribute to its higher physiological maturity (Tański, 2006), which was confirmed by the values of the water/fat ratio in lambs slaughtered at 50 and 100 days of age (54.34 and 41.38, respectively). Meat from younger lambs had a better waterholding capacity and it was lighter in color $(\mathrm{p} \leq 0.01)$ than meat from older lambs. The effect of age at slaughter on the water-holding capacity of lamb meat has also been observed by Grześkowiak et al. (2002). Meat from older lambs had a significantly darker color due to a higher hemoglobin content which resulted from more intensive work of their muscles during rearing. The correlation between meat color and age at slaughter in lambs has also been reported by Brzostowski et al. (1997), Grumbach et al. (2001), Grześkowiak et al. (2002) and Tański (2006). An analysis of the physicochemical properties of lamb meat stored under MA showed that prolonged storage led to an increase in dry matter and total protein concentrations, acidity, energy value and W/P ratio. The color of meat became lighter and its water-holding capacity decreased. Significant changes in the content of dry matter and total protein, energy value, physiological maturity and water-holding capacity were observed as soon as after $10-\mathrm{d}$ storage in MA $(\mathrm{p} \leq 0.05)$. The noted changes became more pronounced after $20 \mathrm{~d}$ ( $\mathrm{p} \leq$ 0.01 ). Between d 20 and 30 of MA storage, the analyzed parameters changed inconsiderably, except for a further significant increase in acidity and a decrease in the W/P ratio. The majority of changes resulted from natural drip loss. An increase in the content of dry matter and other components during long-term storage under modified atmosphere conditions has been also noted by Kondratowicz and Bąk (1999) in pork, and by Krala (1996) in poultry. An increase in meat acidity (a drop in $\mathrm{pH}$ ) over storage may result from the progress of glycolysis, the accumulation of acidic metabolites, mostly lactic acid, and the solubility of $\mathrm{CO}_{2}$ in meat. According to Bąk et al. (2001), Słowiński and Maciejewska (2003), $\mathrm{CO}_{2}$ absorbed by meat forms carbonic acid, thus contributing to a drop in the $\mathrm{pH}$ of meat and its lighter color. Residual oxygen may be left in the package after atmospheric air is removed and the bag is flushed with $\mathrm{N}_{2}$ and $\mathrm{CO}_{2}$. According to Krala (1999), residual oxygen left in MA packages with high $\mathrm{CO}_{2}$ concentrations supports the maintenance of the attractive color of meat. The values of the analyzed physicochemical properties of lamb meat suggest that its quality remained high throughout the storage period.

The fatty acid composition of intramuscular fat (Table 2) was significantly affected by the slaughter age of lambs, and only minimally by the period of MA storage. The intramuscular fat of lambs slaughtered at 50 days of age had higher concentrations of the following fatty acids: $\mathrm{C}_{12: 0}$, $\mathrm{C}_{14: 0}, \mathrm{C}_{15: 0}, \mathrm{C}_{20: 0}, \mathrm{C}_{18: 1}, \mathrm{C}_{20: 1}, \mathrm{C}_{18: 2}, \mathrm{C}_{18: 3}, \mathrm{C}_{20: 4},(\mathrm{p} \leq 0.01)$, and a lower content of $\mathrm{C}_{18: 0}(\mathrm{p} \leq 0.01)$ and $\mathrm{C}_{16 \text { :iso }}(\mathrm{p} \leq 0.05)$, compared with the intramuscular fat of lambs slaughtered at 100 days of age. The differences in the concentrations of individual fatty acids in lamb meat had a significant influence on the proportions of unsaturated and saturated fatty acids (Table 2). The intramuscular fat of lambs slaughtered at 50 days of age, in comparison with the intramuscular fat of lambs slaughtered at 100 days of age, contained lower amounts of SFA $(\mathrm{p} \leq 0.05)$ and higher quantities of MUFA and PUFA $(\mathrm{p} \leq 0.01)$, considered essential fatty acids that should be included in a healthy, well-balanced diet. As demonstrated by Borys and Borys (2001), the nutritional value of meat is determined by the ratio of unsaturated to saturated fatty acids in intramuscular fat. Therefore, from the perspective of human nutrition, meat from younger lambs delivers more health benefits than meat from older lambs. Undesirable age- and weight-related changes in the fatty acid profile of intramuscular fat in lambs have also been reported by Radzik-Rant (1999), Cifini et al. (2000) and Borys et al. (2003). The nutritional value of meat is affected by the PUFA/SFA ratio which should oscillate around 0.45 (Simopoulos, 2004). In the present study, the PUFA/SFA ratio was lower and similar to the value given by Zapletal et al. (2010) for 150-d-old lambs. An age-related decrease in the PUFA/SFA ratio has been previously observed in lambs by Brzostowski et al. (2006) and Brzostowski and Tański (2006).

An analysis of the sensory properties of meat (Table 3) shows that meat from lambs slaughtered at 50 days of age received slightly higher scores for the majority of attributes, in comparison with meat from lambs slaughtered at 100 days of age, and significant differences were noted between groups with respect to taste intensity $(\mathrm{p} \leq 0.05)$. The period of MA storage had no significant effect on aroma intensity, aroma desirability and taste intensity, while prolonged storage led to a decrease in the other parameters. During 30d storage under MA, the scores for the following sensory attributes of lamb meat decreased: taste desirability - from 4.70 to 4.44 points $(p \leq 0.05)$, tenderness - from 4.55 to 4.35 
Table 2. Fatty acid composition of intramuscular fat (\%)

\begin{tabular}{|c|c|c|c|c|c|c|c|}
\hline \multirow{2}{*}{ Specification } & & \multicolumn{2}{|c|}{ Age of lambs (d) } & \multicolumn{4}{|c|}{ Storage in a gas mixture (d) } \\
\hline & & 50 & 100 & 0 & 10 & 20 & 30 \\
\hline \multirow[t]{2}{*}{$\overline{C_{12: 0}}$} & Mean & $0.90^{\mathrm{A}}$ & $0.68^{\mathrm{B}}$ & 0.77 & 0.73 & 0.81 & 0.82 \\
\hline & $\mathrm{SD}$ & 0.30 & 0.15 & 0.28 & 0.20 & 0.27 & 0.27 \\
\hline \multirow[t]{2}{*}{$\mathrm{C}_{14: 0}$} & Mean & $6.62^{\mathrm{A}}$ & $6.06^{\mathrm{B}}$ & 6.11 & 6.30 & 6.56 & 6.51 \\
\hline & SD & 0.96 & 0.82 & 0.78 & 0.86 & 1.02 & 1.03 \\
\hline \multirow[t]{2}{*}{$\mathrm{C}_{15: 0}$} & Mean & $0.67^{\mathrm{A}}$ & $0.56^{\mathrm{B}}$ & 0.63 & 0.56 & 0.59 & 0.62 \\
\hline & SD & 0.11 & 0.08 & 0.14 & 0.08 & 0.08 & 0.07 \\
\hline \multirow[t]{2}{*}{$C_{16: 0 \text { iso }}$} & Mean & $0.37^{\mathrm{b}}$ & $0.41^{\mathrm{a}}$ & $0.47^{\mathrm{Aa}}$ & $0.41^{\mathrm{b}}$ & $0.35^{\mathrm{B}}$ & $0.35^{\mathrm{B}}$ \\
\hline & SD & 0.13 & 0.11 & 0.17 & 0.10 & 0.11 & 0.14 \\
\hline \multirow[t]{2}{*}{$\mathrm{C}_{16: 0}$} & Mean & 26.43 & 26.32 & 25.70 & 25.77 & 26.21 & 26.23 \\
\hline & $\mathrm{SD}$ & 1.92 & 0.89 & 1.45 & 1.08 & 1.40 & 1.85 \\
\hline \multirow[t]{2}{*}{$\mathrm{C}_{17: 0}$} & Mean & 1.13 & 1.11 & 1.16 & 1.09 & 1.10 & 1.12 \\
\hline & $\mathrm{SD}$ & 0.13 & 0.09 & 0.12 & 0.07 & 0.11 & 0.12 \\
\hline \multirow[t]{2}{*}{$\mathrm{C}_{18: 0}$} & Mean & $11.71^{\mathrm{B}}$ & $14.38^{\mathrm{A}}$ & $12.71^{\mathrm{Aa}}$ & $12.43^{\mathrm{b}}$ & $12.00^{\mathrm{b}}$ & $11.92^{\mathrm{Bb}}$ \\
\hline & SD & 1.25 & 0.69 & 1.31 & 0.87 & 1.28 & 0.56 \\
\hline \multirow[t]{2}{*}{$\mathrm{C}_{20: 0}$} & Mean & $0.22^{\mathrm{A}}$ & $0.14^{\mathrm{B}}$ & $0.23^{\mathrm{A}}$ & $0.19^{\mathrm{B}}$ & $0.16^{\mathrm{B}}$ & 0.15 \\
\hline & $\mathrm{SD}$ & 0.08 & 0.03 & 0.09 & 0.04 & 0.03 & 0.04 \\
\hline \multirow[t]{2}{*}{$\mathrm{C}_{14: 1}$} & Mean & 0.67 & 0.77 & 0.68 & 0.66 & 0.69 & 0.68 \\
\hline & $\mathrm{SD}$ & 0.10 & 0.09 & 0.12 & 0.07 & 0.10 & 0.08 \\
\hline \multirow[t]{2}{*}{$\mathrm{C}_{16: 1}$} & Mean & 4.55 & 4.56 & 4.48 & 4.59 & 4.60 & 4.58 \\
\hline & SD & 0.30 & 0.26 & 0.34 & 0.26 & 0.26 & 0.27 \\
\hline \multirow[t]{2}{*}{$\mathrm{C}_{17: 1}$} & Mean & 0.91 & 1.18 & 0.97 & 0.89 & 0.83 & 0.85 \\
\hline & SD & 0.14 & 0.09 & 0.10 & 0.08 & 0.13 & 0.14 \\
\hline \multirow[t]{2}{*}{$\mathrm{C}_{18: 1}$} & Mean & $36.73^{\mathrm{A}}$ & $35.81^{\mathrm{B}}$ & 37.34 & 37.57 & 37.33 & 37.48 \\
\hline & SD & 3.03 & 1.44 & 3.04 & 2.66 & 2.56 & 2.92 \\
\hline \multirow[t]{2}{*}{$\mathrm{C}_{20: 1}$} & Mean & $0.40^{\mathrm{A}}$ & $0.35^{\mathrm{B}}$ & 0.38 & 0.36 & 0.35 & 0.34 \\
\hline & SD & 0.08 & 0.06 & 0.07 & 0.04 & 0.04 & 0.08 \\
\hline \multirow[t]{2}{*}{$\mathrm{C}_{18: 2}$} & Mean & $6.99^{\mathrm{A}}$ & $6.06^{\mathrm{B}}$ & 6.74 & 6.77 & 6.72 & 6.72 \\
\hline & $\mathrm{SD}$ & 0.93 & 0.80 & 1.29 & 1.13 & 0.96 & 0.81 \\
\hline \multirow[t]{2}{*}{$\mathrm{C}_{18: 3}$} & Mean & $0.28^{\mathrm{A}}$ & $0.24^{\mathrm{B}}$ & 0.24 & 0.22 & 0.22 & 0.20 \\
\hline & SD & 0.09 & 0.06 & 0.07 & 0.06 & 0.08 & 0.06 \\
\hline \multirow[t]{2}{*}{$\mathrm{C}_{20: 4}$} & Mean & $1.42^{\mathrm{A}}$ & $1.37^{\mathrm{B}}$ & 1.39 & 1.46 & 1.48 & 1.56 \\
\hline & $\mathrm{SD}$ & 0.42 & 0.46 & 0.43 & 0.38 & 0.47 & 0.42 \\
\hline \multirow[t]{2}{*}{ SFA } & Mean & $48.05^{\mathrm{b}}$ & $49.66^{\mathrm{a}}$ & 47.78 & 47.48 & 47.78 & 47.59 \\
\hline & $\mathrm{SD}$ & 2.52 & 1.61 & 2.67 & 2.45 & 2.77 & 3.12 \\
\hline \multirow[t]{2}{*}{ MUFA } & Mean & $43.26^{\mathrm{A}}$ & $42.67^{\mathrm{B}}$ & 43.85 & 44.07 & 43.80 & 43.93 \\
\hline & $\mathrm{SD}$ & 2.74 & 1.59 & 2.34 & 2.76 & 2.86 & 3.13 \\
\hline \multirow[t]{2}{*}{ PUFA } & Mean & $8.69^{\mathrm{A}}$ & $7.67^{\mathrm{B}}$ & 8.37 & 8.45 & 8.42 & 8.48 \\
\hline & $\mathrm{SD}$ & 1.48 & 1.24 & 2.09 & 1.82 & 1.35 & 1.02 \\
\hline UFA & Mean & $51.95^{\mathrm{a}}$ & $50.34^{\mathrm{b}}$ & 52.22 & 52.52 & 52.22 & 52.41 \\
\hline & SD & 2.31 & 1.62 & 2.67 & 1.64 & 2.77 & 3.13 \\
\hline UFA/SFA & Mean & $1.08^{\mathrm{a}}$ & $1.01^{\mathrm{b}}$ & 1.09 & 1.10 & 1.09 & 1.09 \\
\hline & SD & 0.31 & 0.35 & 0.28 & 0.29 & 0.35 & 0.32 \\
\hline PUFA/SFA & Mean & $0.18^{\mathrm{A}}$ & $0.15^{\mathrm{B}}$ & 0.17 & 0.17 & 0.17 & 0.17 \\
\hline & SD & 0.03 & 0.04 & 0.04 & 0.04 & 0.03 & 0.04 \\
\hline
\end{tabular}

${ }_{\mathrm{a}, \mathrm{b}} \mathrm{p} \leq 0.05{ }^{\mathrm{A}, \mathrm{B}} \mathrm{p} \leq 0.01$

points ( $\mathrm{p} \leq 0.01)$, juiciness - from 4.60 to 4.44 points $(\mathrm{p} \leq 0.01)$. The greatest changes took place between day 20 and 30 of MA storage, when the scores for taste desirability, tenderness and juiciness decreased by $0.15,0.13$ and 0.11 points, respectively. The sensory quality of lamb meat stored under MA was considerably affected by biochemical processes and weight loss. According to Krala (1999), the juiciness of MA packaged meat decreases due to reduced water-holding capacity and interactions between myofibril proteins, water and fat, whereas meat tenderness deteriorates due to an increase in acidity. A close correlation between the $\mathrm{pH}$ and tenderness of meat has been reported 
Table 3. Sensory evaluation of meat (points)

\begin{tabular}{|c|c|c|c|c|c|c|c|}
\hline \multirow{2}{*}{ Specification } & & \multicolumn{2}{|c|}{ Age of lambs (d) } & \multicolumn{4}{|c|}{ Storage in a gas mixture (d) } \\
\hline & & 50 & 100 & 0 & 10 & 20 & 30 \\
\hline \multirow[t]{2}{*}{ Aroma intensity } & Mean & 4.94 & 4.90 & 4.95 & 4.95 & 4.90 & 4.85 \\
\hline & SD & 0.27 & 0.34 & 0.28 & 0.24 & 0.14 & 0.34 \\
\hline \multirow[t]{2}{*}{ Aroma desirability } & Mean & 4.90 & 4.86 & 4.95 & 4.88 & 4.85 & 4.95 \\
\hline & SD & 0.27 & 0.20 & 0.00 & 0.34 & 0.10 & 0.32 \\
\hline \multirow[t]{2}{*}{ Taste intensity } & Mean & $4.86^{\mathrm{a}}$ & $4.59^{\mathrm{b}}$ & 4.75 & 4.75 & 4.73 & 4.66 \\
\hline & $\mathrm{SD}$ & 0.38 & 0.44 & 0.44 & 0.34 & 0.32 & 0.48 \\
\hline \multirow[t]{2}{*}{ Taste desirability } & Mean & $4.68^{\mathrm{a}}$ & $4.61^{\mathrm{b}}$ & $4.70^{\mathrm{A}}$ & $4.65^{\mathrm{A}}$ & $4.60^{\mathrm{A}}$ & $4.44^{\mathrm{B}}$ \\
\hline & $\mathrm{SD}$ & 0.39 & 0.39 & 0.44 & 0.30 & 0.30 & 0.44 \\
\hline \multirow[t]{2}{*}{ Juiciness } & Mean & 4.49 & 4.45 & $4.60^{\mathrm{A}}$ & $4.58^{\mathrm{A}}$ & $4.55^{\mathrm{A}}$ & $4.44^{\mathrm{B}}$ \\
\hline & $\mathrm{SD}$ & 0.63 & 0.56 & 0.64 & 0.40 & 0.45 & 0.76 \\
\hline \multirow[t]{2}{*}{ Tenderness } & Mean & 4.43 & 4.44 & $4.55^{\mathrm{A}}$ & $4.54^{\mathrm{A}}$ & $4.48^{\mathrm{A}}$ & $4.35^{\mathrm{B}}$ \\
\hline & SD & 0.63 & 0.52 & 0.72 & 0.36 & 0.42 & 0.80 \\
\hline \multirow[t]{2}{*}{ Mean score } & Mean & 4.70 & 4.63 & 4.75 & 4.73 & 4.66 & 4.59 \\
\hline & $\mathrm{SD}$ & 0.36 & 0.39 & 0.44 & 0.34 & 0.31 & 0.37 \\
\hline
\end{tabular}

${ }^{\mathrm{a}, \mathrm{b}} \mathrm{p} \leq 0.05{ }^{\mathrm{A}, \mathrm{B}} \mathrm{p} \leq 0.01$.

by Guignot et al. (1994) and Krala (1999). If MA packaged meat products were evaluated based on sensory characteristics, the quality of the studied lamb meat would be considered very good and good over a storage period of 20 and $30 \mathrm{~d}$, respectively. As regards the microbiological quality of meat from lambs slaughtered at 50 and 100 days of age (Figure 1), mesophilic counts were low, at $4.47 \log _{10}$ $\mathrm{CFU} / \mathrm{g}$ and $4.45 \log _{10} \mathrm{CFU} / \mathrm{g}$, respectively, which indicates that the meat intended for MA packaging was fresh, chilled and had a desirable $\mathrm{pH}$. Mesophilic microflora proliferated during storage, and the counts of mesophilic microorganisms remained insignificantly higher in the muscles of younger lambs. After 10 days of MA storage, bacterial counts increased to 5.22 and $5.21 \log _{10} \mathrm{CFU} / \mathrm{g}$ in meat from younger and older lambs, respectively. After 30 days, the respective values reached $6.17 \log _{10} \mathrm{CFU} / \mathrm{g}$ and $6.09 \log _{10} \mathrm{CFU} / \mathrm{g}$. Meat from lambs slaughtered at 50 days of age contained more water, was more delicate and had finer muscle fibers, which is why it was more prone to

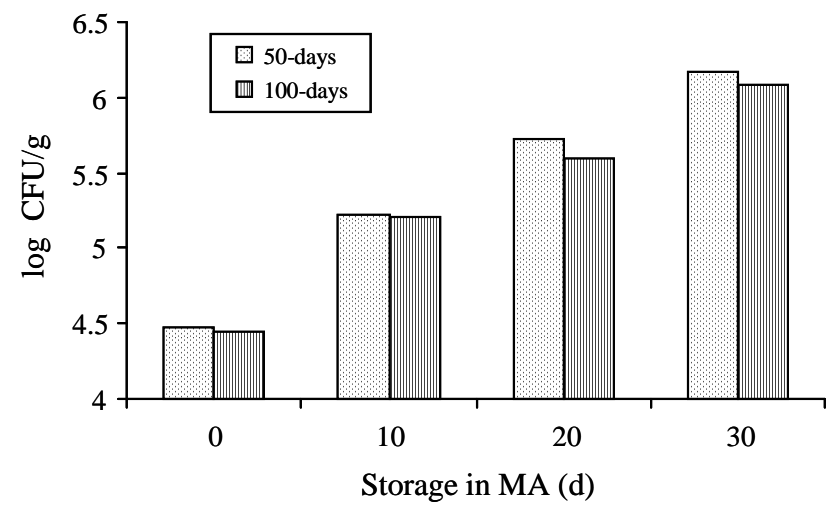

Figure 1. Increase in bacterial counts in lamb meat. bacterial contamination than meat from lambs slaughtered at 100 days of age. The slower proliferation rate of mesophilic bacteria between day 10 and 20 of MA storage resulted from an increase in $\mathrm{CO}_{2}$ concentrations, which disturbed bacterial metabolism. Bacterial cells were unable to multiply rapidly, thus extending the shelf-life of meat. The total microbial counts determined in the analyzed lamb meat did not exceed the maximum permissible levels set at $5 \times 10^{6} \mathrm{CFU} / \mathrm{g}\left(6.7 \log _{10}\right.$ ) in Commission Regulation (EC) No. 2073/2005 on microbiological criteria food foodstuffs. Microbial contamination at a level of 7 to $8 \log _{10} \mathrm{CFU} / \mathrm{g}$ (Krala et al., 1997; Jaremiah, 2001; Kreyenschmidt et al., 2002), manifested by the appearance of undesirable odors and slime formation, renders meat unfit for human consumption. None of the above symptoms were observed in any of the lamb meat samples analyzed in this study.

\section{CONCLUSIONS}

The following conclusions can be drawn from the present study which investigated the quality of meat from Pomeranian lambs slaughtered at 50 and 100 days of age, stored under MA $\left(80 \% \mathrm{~N}_{2}\right.$ and $\left.20 \% \mathrm{CO}_{2}\right)$.

Meat from 100-d-old lambs was characterized by a higher content of dry matter, total protein and crude fat, a darker color and higher physiological maturity, compared with meat from 50-d-old lambs. Meat from lambs slaughtered at 50 days of age was marked by a better waterholding capacity, a lower energy value and higher concentrations of MUFA and PUFA in intramuscular fat.

An increase in the content of dry matter, total protein and energy was noted in MA-stored meat, in comparison with fresh meat. The observed changes were similar in meat 
from 100-d-old and 50-d-old lambs, and they became more pronounced after 20 days of storage.

The studied lamb meat received high scores for sensory properties, it remained safe from microbial contamination during storage and no changes were noted in the fatty acid profile of intramuscular fat. The above indicates that modified atmosphere packaging can be used for prolonging the shelf-life of fresh lamb meat up to 20 (very good results) or even 30 (good results) days.

\section{REFERENCES}

Bąk, T., J. Kondratowicz, J. Denaburski and I. Daszkiewicz. 2001. Możliwości przedłużania trwałości surowca mięsnego w atmosferach ochronnych. Biul. Nauk. UWM, Olst. 13:141-147.

Barrera, O., J. M. Rodríguez-Calleja, J. A. Santos, A. Otero and M. L. García-López. 2007. Effect of different storage conditions on $E$. coli $\mathrm{O} 157: \mathrm{H} 7$ and the indigenous bacterial microflora on lamb meat. Int. J. Food Microbiol. 115:244-251.

Baryłko-Pikielna, N. 1975. Zarys analizy sensorycznej żywności. PWN, Warszawa.

Borys, B. and A. Borys. 2001. Wartość rzeźna i jakość mięsa jagniąt lekkich typu mlecznego i tuczonych do masy ciała 3540 kg. Rocz Nauk. Zoot. Supl., 11:115-124.

Borys, B., A. Jarzynowska and A. Borys. 2003. Jakość zdrowotna mięsa lekkich jagniąt rzeźnych $\mathrm{w}$ zależności od wieku i genotypu. Zesz. Nauk. Przeg. Hod. 68:63-71.

Brzostowski, H., R. Niżnikowski and S. Milewski. 2006. Composition and properties of meat from Pomeranian purebred lambs and their crossbreeds with Berrichon du Cher and Charolaise. Archiv Tierzucht Dummerstorf, 49:494-501.

Brzostowski, H. and Z. Tański. 2006. Nutritional value of the meat of Pomeranian breed lambs and crossbreeds of Black-headed and Texel rams. Archiv Tierzucht Dummerstorf, Special Issue, 49:345-352.

Brzostowski, H. and Z. Tański. 2008. Jakość mięsa jagniąt owcy pomorskiej ich mieszańców przechowywanego w modyfikowanej atmosferze gazów. LXXIII Zjazd Naukowy PTZ. Lublin 26-28.06.2008.

Brzostowski, H. and Z. Tański. 2008. Wpływ wieku uboju jagniąt owcy pomorskiej na wybrane wskaźniki jakości mięsa. LXXIII Zjazd Naukowy PTZ. Lublin 26-28.06.2008.

Brzostowski, H., Z. Tański, S. Milewski and J. Sowińska. 1997. Meat quality of young Kamieniecka rams and Kamieniecka cross-breeds slaughtered at the age of 50 or 100 days. J. Anim. Feed Sci. 6:333-341.

Christopher, F. M., Z. L. Carpenter, C. W. Dill, G. C. Smith and C. Vanderzant. 1980. Microbiology of beef, pork and lamb stored in vacuum or modified gas atmospheres. J. Food Prot. 43:259263.

Cifini, G. F., F. Napolitano, C. Pacelli, A. M. Riviezzi and A. Girolami. 2000. Effect of age at slaughter on carcass traits, fatty acid composition and lipid oxidation of Apulian lambs. Small Rumin. Res. 35:65-70.

Doherty, A. N., J. J. Sheridan, P. Allen, D. A. Mcdowell, I. S. Blair and D. Harrington. 1995. Growth of Yersinia enterocolitica O : 3 on modified atmosphere- packaged lamb. J. Food Microbiol. 12:251-257.
Doherty, A. N., J. J. Sheridan, P. Allen, D. A. Mcdowell and I. S. Blair. 1996a. Physical characteristics of lamb primals packaged under vacuum or modified atmospheres. Meat Sci. 42:315-324.

Doherty, A. N., J. J. Sheridan, P. Allen, D. A. Mcdowell, I. S. Blair and D. Harrington. 1996b. Survival and growth of Aeromonas hydrophila on modified atmosphere packaged normal and high pH lamb. Int. J. Food Microbiol. 28:379-392.

Grau, R. and R. Hamm. 1953. Über das Wasserbindungs Vermögen des toten Saugetiermuskels. I Mitteilung. Der Einfluss des $\mathrm{pH}$ - Wertes auf die Wasserbindung von der zerkleinertem. Rin der Muskel Biochem. I:325-328.

Grumbach, S., K. Nürnberg, W. Zupp, M. Hartung and K. Ender. 2001. Flesch und Fettgualität von Lömmern werschiedener Rassen. Fleischwirtschaft. 4:148-151.

Grześkowiak, E., K. Borzuta, J. Strzelecki, B. Borys, A. Borys and D. Lisiak. 2002. Jakość mięsa lekkich jagniąt rzeźnych w zależności od genotypu i wieku. Zesz. Nauk. Przeg. Hod. 63: 81-89.

Guignol, F., A. Touraille, A. Ouali and M. Renerre. 1994. Relationships between post-mortem $\mathrm{pH}$ changes and some traits of sensory quality in veal. Meat Sci. 37:315-325.

Holland, G. C. 1980. Modified atmospheres for fresh meat distribution. Proc. 33-rd Meat. Ind. Res. Coof. Chicago. II, 21.

INRA. 1988. Institut national de la recherche agronomique. Alimentation des Bovins, Ovins, Caprins (Ed. R. Jarrige). Paris.

Jaremiah, L. E. 2001. Packaging alternatives to deliver fresh meats using short-or long-term distribution. Food Res. Int. 34:749772.

Kaczor, U., S. Ciury and H. Pustkowia. 2000. Parametry jakości mięsa tryczków polskiej owcy długowełnistej oraz jej mieszańców po trykach ras mięsnych. Rocz. Nauk. Zoot. Supl. 8:82-87.

Kondratowicz, J. and T. Bąk. 2001. Effect of storage in the air and controlled atmosphere on its sensory quality. Pol. J. Food Nutr. Sci. 1:41-44.

Krala, L. 1996. Kontrolowana i modyfikowana atmosfera przedłuża trwałość chłodzonego drobiu. Stan badań i wnioski praktyczne. Chłodnictwo 2:35-40.

Krala, L. 1999. Oddziaływanie atmosfery kontrolowanej i modyfikowanej na właściwości chłodzonego mięsa kurcząt. Wyd. Nauk. Polit., Łódzkiej, 255 (rozp. habil.).

Krala, L., D. Kusewicz and A. Pietkiewicz. 1997. Wzrost bakterii w chłodzonym mięsie kurcząt przechowywanym w modyfikowanej atmosferze. Chłodnictwo 4:44-48 .

Kreyenschmidt, J., K. Lohmeyer and N. Stahl. 2002. Charakterisierung des Verderbs von Frischfleisch. Fleischwirtschaft 10:108-111.

Krupiński, J. 2009. Ocena użytkowości mięsnej jagniąt na tle wymogów oraz metod stosowanych w krajach Unii Europejskiej. Inst. Zoot. Państwowy Instytut Badawczy, Kraków, 13-23.

Michniewicz, J. 1998. Pakowanie żywności z zastosowaniem atmosfery modyfikowanej. Chłodnictwo 6:42-44.

Peisker, K. V. 1964. A rapid semi-micro method for preparation of methyl esters from triglycerides using chloroform, methanol, sulphuric acid. J. Am. Oil Chem. Sci. 41:87-88.

Penny, N., S. J. Mott, S. M. Moorhead and R. G. Bell. 1995. 
Preservative packing of bulk packed chilled meat for extended storage life. Meat Industry Researcg Institute of New Zeland, 98:32.

Pikul, J. 2000. Pakowanie i przechowywanie żywności w modyfikowanej atmosferze. Chłodnictwo 9:66-70.

PN-EN ISO 4833:2004. Mikrobiologia żywności i pasz. Horyzontalna metoda oznaczania liczby drobnoustrojów. Metoda płytkowa w temperaturze $30^{\circ} \mathrm{C}$.

Radzik-Rant, A. 1999. Skład kwasów thuszczowych oraz analiza rzeźna tusz jagniąt różnych genotypów ubijanych przy masie 22 i 30 kg. Zesz. Nauk. Przeg. Hod. 43:265-274.

Rokni, N., M. Rezaei-Majaz and S. Bokami. 2001. A comparative study of normal and modified atmosphere packaging and their combination effects with lactic acid on the shelf life of fresh chilled mutton. J. Faul. Vet. Med. Teheran, 56:5-11.

Rozporządzeniem Komisji (WE) nr 2073/2005 z dnia 15 listopada 2005 r. w sprawie kryteriów mikrobiologicznych dotyczących środków spożywczych. Dziennik Urzędowy Unii Europejskiej L.338/1.

Sheridan, J. J., A. Doherty, P. Allen, D. A. McDowell, I. S. Blair and D. Harrington. 1997. The effect of vacuum and modified atmosphere packaging on the shelf-life of lambs, stored at different temperatures. Meat Sci. 1:107-117.

Simopoulos, A. P. 2004. Omega-6/Omega-3 essential fatty acid ratio and chronic diseases. Food Rev. Int. 20:70-90.
Słowiński, M. P. and A. Maciejewska. 2003. Wpływ metody pakowania na trwałość elementów z kurcząt przechowywanych w warunkach chłodniczych. Mięso i Wędliny, 6:30-35.

Tański, Z. 2006. Jakość mięsa jagniąt owcy pomorskiej, ile de france i ich mieszańców przechowywanego w stanie zamrożonym oraz w modyfikowanej atmosferze gazów. Rozprawy i monografie UWM Olsztyn, 123:1-60.

Tański, Z., H. Brzostowski, S. Milewski, K. Ząbek and K. Kosińska. 2009. Effect of the age of ile de France lambs on the quality and properties of meat. EAAP - 60th Annual Meeting, Barcelona, Spain 24-27 August. Book of Abstracts No 15, S 41, s. 476.

Vergara, H. and L. Gallego. 2001. Effects of composition in modified atmosphere packaging on the meat quality of Spanish Manchega lamb. J. Sci. Food Agric. 8:1353-1357.

Weber, H. and H. U. Höpke. 1980. Der Einflus einer kontrolliren Atmosphärre bestchend aus 20\% $\mathrm{CO}_{2}$ und $80 \% \mathrm{~N}_{2}$ and die Haltbarkeit von portioniertem, verpackten Rindfleisch. Fleischwirtschaft 2:364-384.

Zapletal, D., J. Kuchtik and I. Dobes. 2010. The effect of genotype on the chemical and fatty acid composition on the quadriceps femoris muscle in extensively fattened lambs. Archiv Fur Tierzucht, 53:589-599.

Żeglarska, Z., K. Markiewicz and S. Smoczyński. 1979. Skład kwasów thuszczowych tłuszczu mięśniowego oraz tłuszczów zapasowych królików. Zesz. Nauk. ART Olsztyn, 15:167-177. 